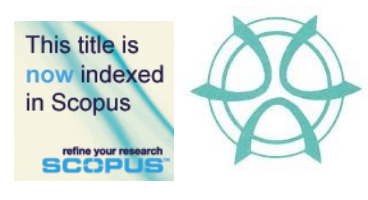

PLANNING MALAYSIA:

Journal of the Malaysian Institute of Planners

VOLUME 16 ISSUE 2 (2018), Page 164 - 174

\title{
IN PURSUIT OF ECONOMICALLY COMPETITIVE AGRO-TOURISM SECTOR: THE CASE OF TERENGGANU HOMESTAY, MALAYSIA
}

\author{
Syahriah Bachok ${ }^{1}$, Tuan Anisdina Tuan Mohd Amin ${ }^{2}$ \& Syakir Amir Ab \\ Rahman $^{3}$ \\ ${ }^{1,2,3}$ Kulliyyah of Architecture and Environmental Design, \\ INTERNATIONAL ISLAMIC UNIVERSITY MALAYSIA
}

\begin{abstract}
Agro-tourism is more than just a tourist product. It is a journey to a new sensation or positive behavior concerning the environment, the community and culture. It also one of the diversified sub-sectors that provide opportunities and choices for the rural community, commonly associated with agricultural activities to enhance and maintain their economic sustainability. This research focuses on the quantification of tourism sector income specifically related to agricultural destinations, activities, and products, evaluated in the selected communities that offer tourists visits and stays within the former's villages or settlements. Income derived from the activities, destinations, and products are to be reported and assessed against initial investment and annual operating costs. This is an area mostly void of literature, especially those within the Malaysian contexts. The research aims at exploring the vitality and robustness of agro-tourism based homestay activities in Terengganu. Three objectives have been developed based on the gaps in existing literature. Firstly, the research is to identify offerings of homestay destinations, activities, and products relevant to agriculture sector within the rural communities of Terengganu. Secondly, the research is to assess the income received from these activities based on communal receipts as well as individually reported revenues. Finally, the research is to recommend strategic and focused areas of improvement to increase and sustain the competitiveness of agro-tourism sector delivered through homestays operation. The methods used in this paper were the semi-structured interview and focus group discussion. 76 respondents participated in the discussion.
\end{abstract}

Keyword: homestay, agro-tourism, homestay operation, tourism, Terengganu 
PLANNING MALAYSIA

Journal of the Malaysia Institute of Planners (2018)

\section{INTRODUCTION}

Tourism is one of the ways to increase the economy of the country. In 2016, there were 26.76 million tourist arrivals in Malaysia with total receipt of RM82.1 billion. This is a slight increase from the previous year which is 25.7 million tourists with the total receipt of RM69.12 billion (MOTAC, 2016). In the 11th Malaysian plan, the government's focus is on the development of rural communities through transforming rural areas to elevate well-being of rural communities. The rural population involved in agricultural activities and have dwelling facilities to offer experiences of cultural and agro-based daily activities were facilitated to engage in income generation opportunities. Then, the Ministry of Tourism and Culture of Malaysia introduced a homestay program in 1988 as an alternative accommodation for tourists (Kayat \& Mohd Nor, 2006). A homestay is a form of accommodation where tourists will be able to live with selected host families and have the opportunity to interact and experience the daily way of life of the family and culture directly Malaysia (MOTAC, 2014). Abdul Razzaq et al. (2011) stated in their research that the income of homestay operators increased from RM1000 to RM1500 after their participation in the homestay program. There are many Malaysian tourism products introduced to the tourist through homestay programs. Besides exploring the vitality and robustness of agro-tourism based homestay activities in Terengganu, a state which is rich with natural resources and cultural heritage, the problem faced by homestay owners should be highlighted. Mohd Nor and Kayat (2010) mentioned in their study that challenges faced by homestay owners might affect the success of homestays program. This paper is organized as follows. In section 2, there will be an enlightenment on related case study area. In section 3, the methodology used in acquiring data. The results from the data analyzed are also presented in section 4. Finally, the work of this paper is summarized in the last section.

\section{CASE STUDIES}

Among the important rural tourism in Malaysia is homestay programme. It is a community-based programme where tourists can have interaction and direct experience of the day-to-day life of the community (Bhattarai, 2012). Besides, Boonratana (2010) and Pusiran \& Xiao (2007) supported that homestay provides an excellent opportunity to tourists to experience the way of life of the local people of an area along with the indigenous and traditional cultures within a comfortable home setting. It is a program under the Rural Tourism Master Plan, which aims to encourage the participation of rural communities in the tourism sector. 
Syahriah Bachok, Tuan Anisdina Tuan Mohd Amin \& Syakir Amir Ab Rahman

In Pursuit of Economically Competitive Agro-Tourism Sector: The Case of Terengganu Homestay, Malaysia

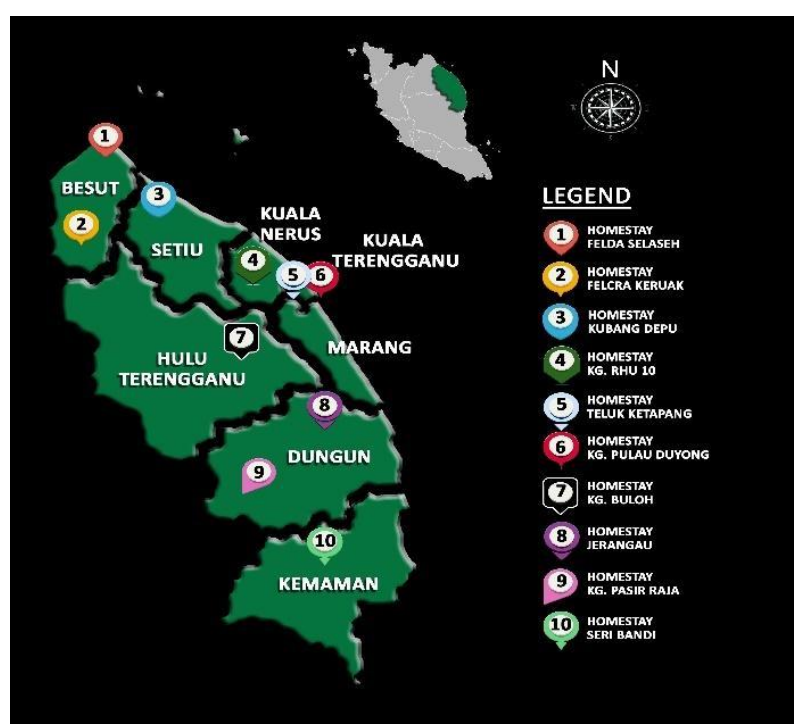

Figure 1: Location map of Terengganu

In Terengganu, there are ten (10) registered homestays that were actively operating. Figure 1 shows the map of Terengganu clustered homestays that were operated under Ministry of Tourism and Culture (MOTAC). Homestay development was partially developed around agro-based industry including small rural centers in Felda settlements. In fact, two of registered homestays in Terengganu was located at the heart of Felda settlements (MOTAC, 2014). 
PLANNING MALAYSIA

Journal of the Malaysia Institute of Planners (2018)

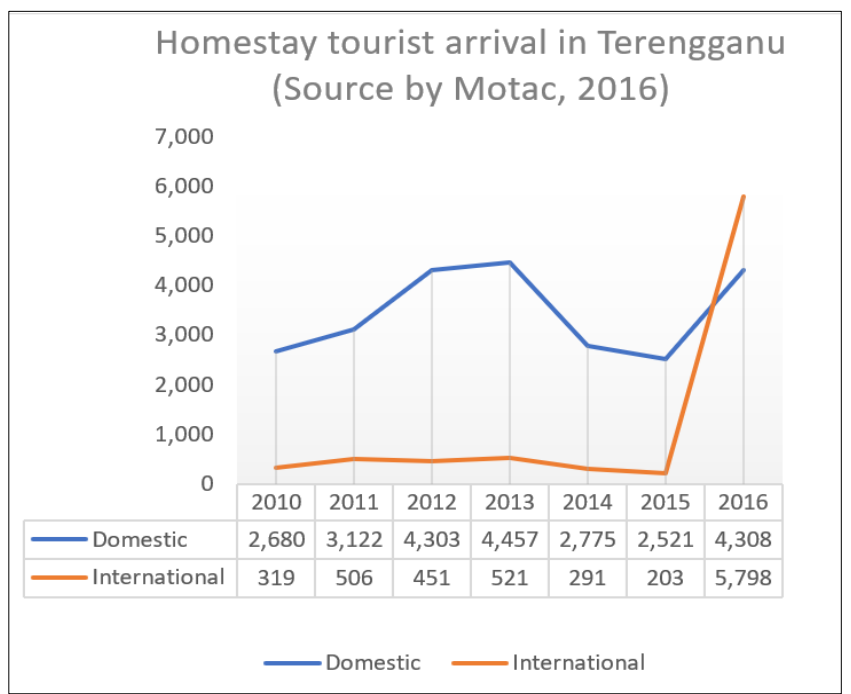

Figure 2: Homestay tourist arrival

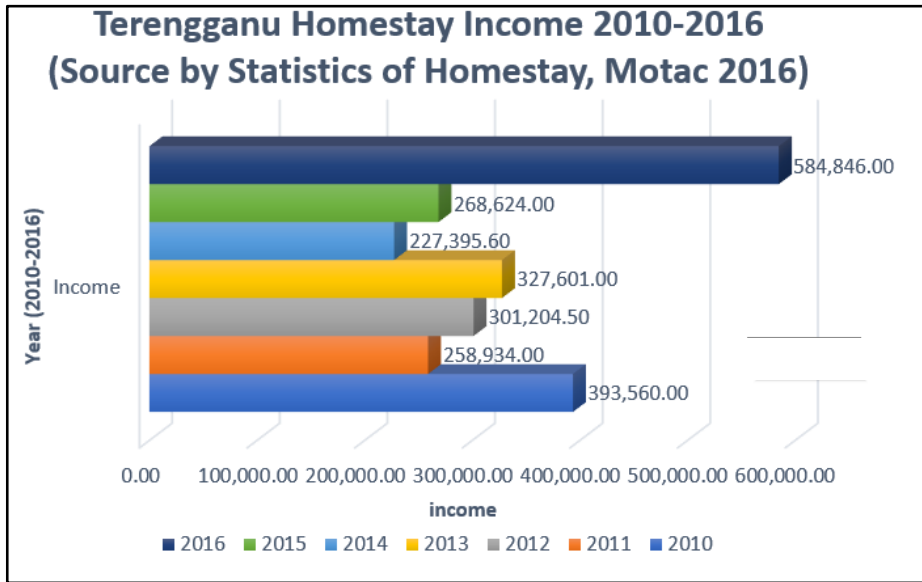

Figure 3: Terengganu homestay income

Figure 2 above shows the Terengganu tourist arrival of homestay for the year 2010 - 2016. The number of tourists was increasing starting from 2010 until 2013. However, the number fluctuated after year 2013. Same goes for the income of Terengganu homestays. The income fluctuated between year 2010 and year 2015 (Figure 3). However, the income increased between year 2015 and 2016. 
Syahriah Bachok, Tuan Anisdina Tuan Mohd Amin \& Syakir Amir Ab Rahman

In Pursuit of Economically Competitive Agro-Tourism Sector: The Case of Terengganu Homestay, Malaysia

\section{METHODOLOGY}

\section{Data Collection}

There were two types of data collection which were secondary and primary data. For the secondary data, the data was collected from tourism local authorities. For the primary data, semi-structured interview and focus group discussion session were carried out on homestay operators in identifying factors relating to homestay programs, activities of agro and non-agro based, and income generated. The questionnaire survey consisted of the sociodemographic part, operational homestay and also income part. There were 76 homestay operators from eight (8) homestays that participated in the interview sessions. They were Homestay of Felcra Keruak (8), Homestay of Teluk Ketapang (5), Homestay of Felda Selasih (18), Homestay of Jerangau (9), Homestay of Kg Pasir Raja (20), Homestay of Rhu 10 (5), Homestay of Kubang Depu (6) and Homestay of Seri Bandi (5).

\section{Sampling and Data Analysis}

The focus group discussion (FGD) was conducted between enumerators and homestay operators on an agreed date during the weekend. The head of the homestay gathered as many homestay operators as possible. The moderator briefed on the questionnaires prior to answering the questions. The survey was assisted by the enumerators. Each enumerator had three to five homestay operators to be assisted. 76 homestay operators had been voluntarily interviewed during FGD. Then, transcription work would be conducted using SPSS to highlight frequency, pattern, and trends in the responses. Test of significance were conducted on factors influencing the motivation, success, and failure of homestay concept and operations.

\section{DATA ANALYSIS AND RESULTS}

\section{Sociodemographic}

The first part of questionnaire survey and session of focus group discussion was on the homestay owners' sociodemographic profile. Table 1 shows the frequency distribution of each socio demographic profile variables including gender, age, employment, household members and monthly household income. The highlighted number indicated the highest frequency of homestay owners. It was discovered that most of the homestay owners was self-employed females aging between 50 and 59 years old. The number of households was the factor of their participation in homestay programs. Most of the operators or homestay owners live together with their spouse and most of them had a child. The majority of homestay owners were low-income earners with monthly income of RM10001999. 
PLANNING MALAYSIA

Journal of the Malaysia Institute of Planners (2018)

Table 1: Sociodemographic of homestay operators

\begin{tabular}{llcc}
\hline Sociodemographic & Descriptions & $(\mathrm{fq})$ & $\%$ \\
\hline \multirow{2}{*}{ Gender } & Male & 25 & 32.8 \\
& Female & $\mathbf{5 1}$ & $\mathbf{6 7 . 2}$ \\
\hline \multirow{4}{*}{ Age } & $19-39(\mathrm{y} / \mathrm{o})$ & 5 & 6.5 \\
& $40-49(\mathrm{y} / \mathrm{o})$ & 15 & 19.7 \\
& $50-59(\mathrm{y} / \mathrm{o})$ & $\mathbf{2 9}$ & $\mathbf{3 8 . 1}$ \\
& $60-69(\mathrm{y} / \mathrm{o})$ & 27 & 35.5 \\
\hline \multirow{5}{*}{ Employment } & Self-employed & $\mathbf{3 7}$ & $\mathbf{4 8 . 7}$ \\
& Private Sector & 9 & 11.8 \\
& Public Sector & 11 & 14.5 \\
& Retiree & 9 & 11.8 \\
Household members & Housewife & 10 & 13.2 \\
\hline \multirow{5}{*}{ Household monthly income (RM) } & $0-1$ person & $\mathbf{5 5}$ & $\mathbf{7 2 . 3}$ \\
& $2-3$ person & 18 & 23.6 \\
& $4-5$ person & 3 & 3.9 \\
\hline & Below 999 & 17 & 22.3 \\
& $1000-1999$ & $\mathbf{2 5}$ & $\mathbf{3 2 . 8}$ \\
& $2000-2999$ & 20 & 26.3 \\
& $3000-3999$ & 9 & 11.8 \\
& $4000-4999$ & 3 & 3.9 \\
\hline
\end{tabular}

\section{Homestay Operations}

Data collection of homestay operations consists of the year of start, homestay investment, break-even, homestay monthly expenses and subsidy as stated in Table 2 below. Based on Table 2, all the homestay owners received training from MOTAC and INFRA. Majority of homestay owners started the operation of the homestays since year 1996 (34.2\%). Since most of the homestay owners invested less than RM2000, the break-even period was shorter; within 5 years. The monthly expenses of homestay were also mostly in the range of RM100 to RM999. Only 19.7\% of homestay owners received subsidy from MOTAC. Based on the discussion with the homestay operators, the subsidy received after homestay inspections from MOTAC officers covered room and toilet renovations.

Table 2: Homestay operation

\begin{tabular}{lccc}
\hline Operational of homestay & Description & (fq) & $\%$ \\
\hline Year of start & $\mathbf{1 9 9 6}$ & $\mathbf{2 6}$ & $\mathbf{3 4 . 2}$ \\
& 2003 & 7 & 9.2 \\
2009 & 16 & 21 \\
& 2013 & 4 & 5.2 \\
& 2014 & 8 & 10.5
\end{tabular}


Syahriah Bachok, Tuan Anisdina Tuan Mohd Amin \& Syakir Amir Ab Rahman

In Pursuit of Economically Competitive Agro-Tourism Sector: The Case of Terengganu Homestay, Malaysia

\begin{tabular}{lccc}
\hline & 2015 & 1 & 1.3 \\
& 2016 & 9 & 11.8 \\
Training & N/A & 5 & 6.5 \\
\hline Initial Investment (RM) & Yes & $\mathbf{7 6}$ & $\mathbf{1 0 0}$ \\
& No & 0 & 0 \\
\hline Expected Break-even & below 2000 & $\mathbf{4 9}$ & $\mathbf{6 4 . 4}$ \\
& $2001-4999$ & 2 & 2.6 \\
& $5000-7999$ & 11 & 14.4 \\
& 8000 above & 14 & 18.4 \\
\hline Homestay monthly expenses (RM) & $\mathbf{0 - 5}$ years & $\mathbf{4 6}$ & $\mathbf{6 0 . 5}$ \\
& $5-10$ years & 8 & 10.5 \\
& 11 years above & 8 & 10.5 \\
& N/A & 14 & 18.4 \\
\hline Subsidy & $\mathbf{1 0 0}-\mathbf{9 9 9}$ & $\mathbf{4 0}$ & $\mathbf{5 2 . 6}$ \\
& $1000-1999$ & 27 & 35.5 \\
& 2000 above & 9 & 11.8 \\
\hline
\end{tabular}

\section{Stayers of Homestay}

The requirement of homestay program participation was the provisions of a minimum of one standard room. The room should not be separated outside of the house. Most of the homestay owners provided one room for tourist with the percentage of $57.8 \%$. The rental cost of homestay was normally standardized by the head of the homestay. Based on table 3 below, the majority of the owners charged between of RM51 and RM100 per night and per person (including food). An average number of tourist were two or three persons monthly with the minimum stay of duration of two nights (55\%).

Table 3: Stayers of homestay

\begin{tabular}{cccc}
\hline Stayers of homestay & Description & $\mathrm{Fq}$ & $\%$ \\
\hline \multirow{3}{*}{ Rooms } & $\mathbf{1}$ & $\mathbf{4 4}$ & $\mathbf{5 7 . 8}$ \\
& 2 & 22 & 28.9 \\
& 3 & 4 & 5.2 \\
& 4 above & 6 & 7.8 \\
\hline \multirow{3}{*}{ Rental cost (RM) } & RM50 below & 27 & 35.5 \\
& $\mathbf{R M 5 1 - R M 1 0 0}$ & $\mathbf{4 4}$ & $\mathbf{5 7 . 8}$ \\
& RM101 above & 5 & 6.5 \\
\hline \multirow{3}{*}{ Monthly No. of tourist } & $\mathbf{1 - 2}$ person & $\mathbf{5 4}$ & $\mathbf{7 1}$ \\
& 3-4 person & 11 & 14.4 \\
& 5 person above & 6 & 7.8 \\
& N/A & 5 & 6.5 \\
\hline Stay durations & 1 night & 3 & 3.9
\end{tabular}


PLANNING MALAYSIA

Journal of the Malaysia Institute of Planners (2018)

\begin{tabular}{ccc}
\hline 2 nights & $\mathbf{5 5}$ & $\mathbf{7 2 . 3}$ \\
3 nights & 9 & 11.8 \\
4 nights above & 4 & 5.2 \\
N/A & 5 & 6.5 \\
\hline
\end{tabular}

\section{Homestay activities and products}

The geographical aspect of location was also important in identifying the attraction such as visiting the indigenous at homestay of Felcra Keruak, and hiking to Gunung Tebu at homestay of $\mathrm{Kg}$ Pasir Raja. The first objective of identifying the homestays destination, activities and products was achieved. Table 4 shows that the highest percentage of homestay activities were traditional culture, cooking traditional food, village touring, agriculture product and handicraft with the percentage of $94.7 \%, 92.1 \%, 89.4 \%$, and $84.2 \%$ respectively. The activities based on homestays were shown in Table 5 .

Table 4: Homestay activities and products

\begin{tabular}{|c|c|c|c|c|c|c|}
\hline \multirow{2}{*}{ Tourism Activities } & \multicolumn{2}{|c|}{ Yes } & \multicolumn{2}{|c|}{ No } & \multicolumn{2}{|c|}{ Total } \\
\hline & $(\%)$ & Freq & $(\%)$ & Freq & $(\%)$ & Freq \\
\hline 1. Rubber tapping & 47.3 & 36 & 52.6 & 40 & 100.0 & 76 \\
\hline 2. Palm oil processing & 53.9 & 41 & 46.0 & 35 & 100.0 & 76 \\
\hline 3. Aquaculture & 44.7 & 34 & 55.2 & 42 & 100.0 & 76 \\
\hline 4. Fishing/ boat trip & 57.8 & 44 & 42.1 & 32 & 100.0 & 76 \\
\hline 5. Turtle hatching & 5.2 & 4 & 94.7 & 72 & 100.0 & 76 \\
\hline 6. Agriculture product \& handicraft & 84.2 & 64 & 15.7 & 12 & 100.0 & 76 \\
\hline 7. River cruising & 69.7 & 53 & 30.2 & 23 & 100.0 & 76 \\
\hline 8. Village touring & 89.4 & 68 & 10.5 & 8 & 100.0 & 76 \\
\hline 9. Fireflies watching & 13.1 & 10 & 86.8 & 66 & 100.0 & 76 \\
\hline 10. Traditional culture & 94.7 & 72 & 5.2 & 4 & 100.0 & 76 \\
\hline 11. Visiting historical sites & 57.8 & 44 & 42.1 & 32 & 100.0 & 76 \\
\hline $\begin{array}{l}\text { 12. Cooking traditional food } \\
\text { activity }\end{array}$ & 92.1 & 70 & 7.8 & 6 & 100.0 & 76 \\
\hline
\end{tabular}

Table 5: Homestay activities based on location

\begin{tabular}{lccccccccccccccc}
\hline Homestay & \multicolumn{110}{c}{} & \multicolumn{110}{c}{ Activities based on homestay } \\
\cline { 2 - 6 } & 1 & 2 & 3 & 4 & 5 & 6 & 7 & 8 & 9 & 10 & 11 & 12 \\
\hline Felcra Keruak & $\sqrt{ }$ & 0 & $\sqrt{ }$ & $\sqrt{ }$ & 0 & $\sqrt{ }$ & $\sqrt{ }$ & $\sqrt{ }$ & 0 & $\sqrt{ }$ & $\sqrt{ }$ & $\sqrt{ }$ \\
Teluk Ketapang & $\sqrt{ }$ & 0 & $\sqrt{ }$ & 0 & 0 & $\sqrt{ }$ & $\sqrt{ }$ & $\sqrt{ }$ & $\sqrt{ }$ & $\sqrt{ }$ & $\sqrt{ }$ & $\sqrt{ }$ \\
Felda Selaseh & $\sqrt{ }$ & $\sqrt{ }$ & $\sqrt{ }$ & $\sqrt{ }$ & $\sqrt{ }$ & $\sqrt{ }$ & $\sqrt{ }$ & $\sqrt{ }$ & 0 & $\sqrt{ }$ & $\sqrt{ }$ & $\sqrt{ }$ \\
Jerangau & $\sqrt{ }$ & $\sqrt{ }$ & $\sqrt{ }$ & $\sqrt{ }$ & 0 & $\sqrt{ }$ & $\sqrt{ }$ & $\sqrt{ }$ & 0 & $\sqrt{ }$ & $\sqrt{ }$ & $\sqrt{ }$ \\
Pasir Raja & $\sqrt{ }$ & $\sqrt{ }$ & $\sqrt{ }$ & $\sqrt{ }$ & 0 & $\sqrt{ }$ & $\sqrt{ }$ & $\sqrt{ }$ & 0 & $\sqrt{ }$ & $\sqrt{ }$ & $\sqrt{ }$ \\
Rhu 10 & 0 & 0 & $\sqrt{ }$ & $\sqrt{ }$ & 0 & $\sqrt{ }$ & $\sqrt{ }$ & $\sqrt{ }$ & $\sqrt{ }$ & $\sqrt{ }$ & $\sqrt{ }$ & $\sqrt{ }$
\end{tabular}


Syahriah Bachok, Tuan Anisdina Tuan Mohd Amin \& Syakir Amir Ab Rahman

In Pursuit of Economically Competitive Agro-Tourism Sector: The Case of Terengganu Homestay, Malaysia

Kubang Depu

Seri Bandi

\begin{tabular}{llllllllllll}
$\sqrt{ }$ & $\sqrt{ }$ & $\sqrt{ }$ & $\sqrt{ }$ & $\sqrt{ }$ & $\sqrt{ }$ & $\sqrt{ }$ & $\sqrt{ }$ & 0 & $\sqrt{ }$ & $\sqrt{ }$ & $\sqrt{ }$ \\
$\sqrt{ }$ & $\sqrt{ }$ & $\sqrt{ }$ & $\sqrt{ }$ & $\sqrt{ }$ & $\sqrt{ }$ & $\sqrt{ }$ & $\sqrt{ }$ & $\sqrt{ }$ & $\sqrt{ }$ & $\sqrt{ }$ & $\sqrt{ }$ \\
\hline
\end{tabular}

\section{Homestay Program Income}

In order to achieve the second objective of this study, the income received from the homestay products was assessed. Income of homestays was generated from the homestays fee including stays, food, activity and also from the selling of local product such as souvenir, fish chips, fruits, kelulut-honey and others. $43 \%$ of homestay owners or operators had an average income of RM 101 to RM 300 per month. The dependency of income on homestay program was weak, hence to continue the homestay program seemed futile. However, most of the owners participated in this program due to their interest and wished to remain in the homestay business.

\section{Possible Challenges}

The challenges that were faced by the homestay owners was recorded during the discussion. Figure 4 below shows that competitor was the main problems challenged by homestay owners (35\%). The misunderstanding of the homestay concept was due to unregistered rental house or accommodation operators that used the term 'homestay' for their business. Thus led to confusion among tourists. The second highest was the natural disaster (flood) especially in the area of Jerangau Homestay (29\%). The geographical aspect of location and improper drainage planning were the factors of the flood during heavy rain especially between November and January. The priority of family over tourists during the holidays and communication barriers also posed as challenges $(12 \%$ respectively). 
PLANNING MALAYSIA

Journal of the Malaysia Institute of Planners (2018)

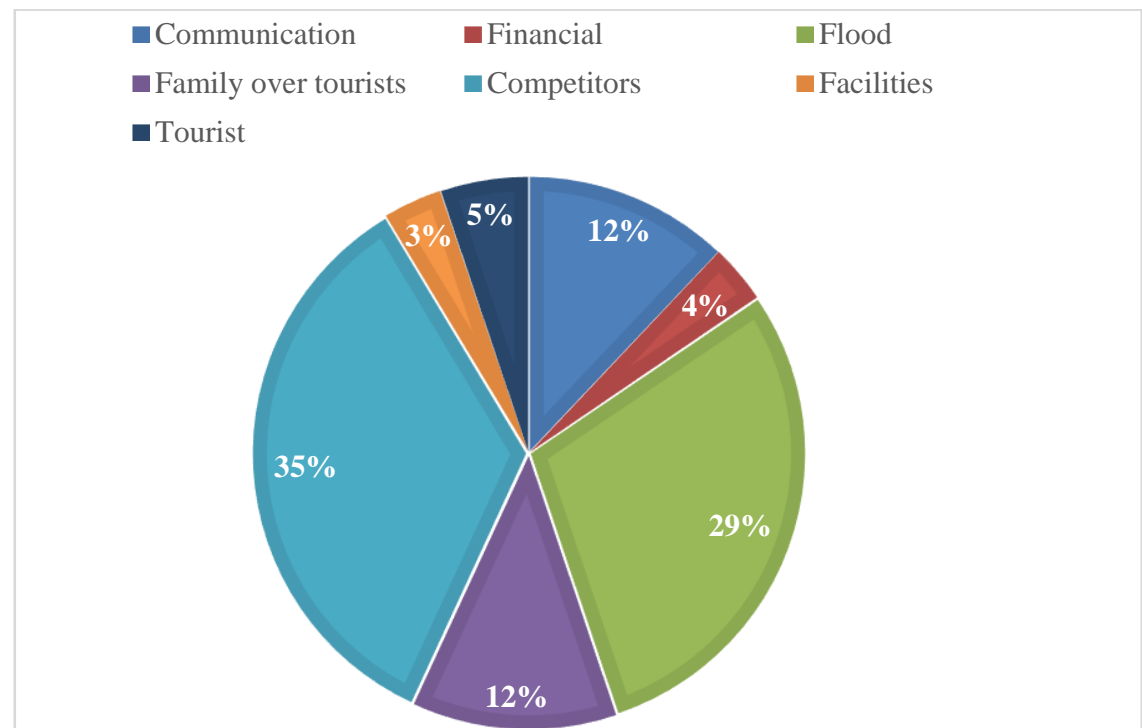

Figure 4: Possible challenges

\section{CONCLUSION AND RECOMMENDATIONS}

There are several conclusions and recommendations that can be made from the results. The identification of destinations, activities and also tourism products was derived from the site visits. Homestay program benefits the community and it is the secondary tourism package for the tourists. The government should formulate the homestay policy and enhance the program since the program acquire the common interest from both the locals and the tourists. The income that was generated from the homestay program was low which range from RM 101 to RM 300 per month. It was stated that the problem faced by the homestay operators influenced the tourists' options. The term 'homestay' is referred to the homestay program under the supervision of MOTAC. It should strictly be used befittingly to avoid further confusion among tourists. The drainage system should also be properly managed to control the flood. Additionally, the enhancement through professional workshop of basic communication and promotion skills is crucial. Homestays should be located according to specialty and availability of tourism activities at respective location. For example; Homestay of Teluk Ketapang was located at the center of Kuala Terengganu. The tourists were introduced to the cultural activity such as traditional cuisine preparations, local traditional dancing, traditional musical instruments and also crafting. The Felda Keruak Homestay was more related to the agro-based activity such as farm visit.

\section{ACKNOWLEDGEMENT}

This work was supported in part by International Islamic University of Malaysia under Grant Nos. SP16-034-0247 
Syahriah Bachok, Tuan Anisdina Tuan Mohd Amin \& Syakir Amir Ab Rahman

In Pursuit of Economically Competitive Agro-Tourism Sector: The Case of Terengganu Homestay, Malaysia

\section{REFERENCES}

Abdul Razzaq, A. R., Hadi, M. Y., Mustafa, M. Z., Hamzah, A., Khalifah, Z., \& Mohamad, N. H. (2011). Local community participation in homestay program development in Malaysia. Journal of Modern Accounting and Auditing, 7(12), 1418-1429.

Bhattarai, T. (2012, September 10). Homestay Boost Tourism in Rural Nepal. Global Press Journal. Retrieved from https://globalpressjournal.com/asia/nepal/homestays-boost-tourism-in-ruralnepal/

Boonratana, R. (2010). Community-based tourism in Thailand: The need and justification for an operational definition. Kasetsart Journal of Social Sciences, 31, 280-289.

Kayat, K. \& Mohd Nor, N. A. (2006). Penglibatan ahli komuniti dalam Program Pembangunan Komuniti: Satu kajian ke atas program homestay di Kedah. Akademika, 67, 77-102.

Ministry of Tourism and Culture [MOTAC] (2014). Malaysia homestay statistics.

Ministry of Tourism and Culture [MOTAC] (2016). Malaysia homestay statistics.

Mohd Nor, N. A. \& Kayat, K. (2010, December). The challenges of community-based homestay programme in Malaysia. Regional Conference on Tourism Research. December 13-14, 2010, Penang, Malaysia

Pusiran, A. K., \& Xiao, H. (2013). Challenges and community development: A case study of homestay in Malaysia. Asian Social Science, 9(5), 1-17. 